\title{
Hemolytic Disease of the Newborn Caused by a New Deletion of the Entire $\beta$-Globin Cluster
}

\author{
Mario Pirastu and Yuet Wai Kan, Howard Hughes Medical Institute Laboratory \\ and the Division of Medical Genetics and Molecular Hematology, \\ Department of Medicine, University of California, \\ San Francisco, California 94143 \\ C. C. LiN, Department of Pediatrics and Medical Biochemistry, University of \\ Calgary, Calgary, Alberta, Canada T2N 4NI \\ Rosalie M. Baine, Department of Health and Human Services, Centers for \\ Disease Control, Atlanta, Georgia 30333
C. Tate Holbrook, Department of Pediatrics, East Carolina University School of Medicine, Greenville, North Carolina 27834

\begin{abstract}
A в S TR A C T We describe a new type of $\gamma \delta \beta$-thalassemia in four generations of a family of Scotch-Irish descent. The proposita presented with hemolytic disease of the newborn, which was characterized by a microcytic anemia. Initial restriction endonuclease analysis of the DNA showed no grossly abnormal patterns, but studies of polymorphic restriction sites and gene dosage revealed an extensive deletion that removed all the $\beta$ - and $\beta$-like globin genes from the affected chromosome. In situ hybridization of chromosome preparations with radioactive $\beta$-globin gene probes showed that only one $11 \mathrm{p}$ homolog contained the $\beta$-globin gene cluster in the affected family members.
\end{abstract}

\section{INTRODUCTION}

The human $\beta$-globin gene cluster lies on the short arm of chromosome $11(1,2)$ in the order $\epsilon-{ }^{\mathrm{G}} \gamma-{ }^{\mathrm{A}} \gamma-\psi \beta-\delta-\beta$ (3). Many different DNA deletions, varying in length from a single nucleotide to thousands of base pairs, affect the globin genes (4). In the $\beta$-globin cluster, deletion produces either the genotypes of $\beta$-thalassemia $(5), \delta \beta$-thalassemia $(6,7)$, hereditary persistence

Dr. Kan is an investigator of the Howard Hughes Medical Institute.

Received for publication 27 December 1982 and in revised form 6 April 1983. of fetal hemoglobin $(\mathrm{HPFH})^{1}(6-9)$, or $\gamma \delta \beta$-thalassemia $(10,11)$.

$\gamma \delta \beta$-Thalassemia is an uncommon clinical syndrome that produces hemolytic disease in the newborn (10, 12). Unlike the common form of $\beta$-thalassemia that has no clinical manifestations at birth, newborns heterozygous for $\gamma \delta \beta$-thalassemia present with microcytic hemolytic anemia and normoblastemia. The acute hemolytic episodes usually subside after the neonatal period, but the erythrocyte morphology of thalassemia trait persists. Adults with this disorder have normal $\mathrm{Hb}$ $A_{2}$ and $F$ levels and an $\alpha / \beta$ globin chain synthetic ratio of $\sim 2.0$. Two extensive deletions involving more than 60,000 base pairs $(60 \mathrm{~kb})$ of DNA on chromosome 11 have been associated with this syndrome. Both involve the $\epsilon-,{ }^{\mathrm{G}} \gamma-,{ }^{\mathrm{A}} \gamma-, \psi \beta$-, and $\delta$-globin loci; one stops just upstream from the $\beta$-locus and leaves the entire $\beta$ globin gene intact (10) and the other includes the $5^{\prime}$ portion of the $\beta$-globin gene but leaves the $3^{\prime}$ portion (11). Southern analysis of genomic DNA from these syndromes using a $\beta$-globin gene probe revealed $a b-$ normal patterns with many restriction enzymes.

This report describes an extensive new DNA deletion that also produces the $\gamma \delta \beta$-thalassemia syndrome. The deletion removes the entire $\beta$-globin gene cluster from the affected chromosome.

\footnotetext{
${ }^{1}$ Abbreviations used in this paper: HPFH, hereditary persistence of fetal hemoglobin; IVS, intervening sequence.
} 


\section{METHODS}

The proposita, the second child of Scotch-Irish parents, was delivered by repeat Caesarian section at the 37 th week of gestation. Bile-stained amniotic fluid was noted. The mother had type $\mathrm{B}$ blood, $\mathrm{Rh}^{+}$, and the infant had type $\mathrm{O}, \mathrm{Rh}^{+}$, with negative direct and indirect Coomb's test. The proposita weighed $2,660 \mathrm{~g}$ and was $49 \mathrm{~cm}$ long. Head circumference was $31 \mathrm{~cm}$. Multiple purpuric lesions were noted on the skin and mucous membranes. The liver was $3 \mathrm{~cm}$ and the spleen $2 \mathrm{~cm}$ below the costal margin. Hemoglobin was $8.6 \mathrm{~g} / \mathrm{dl}$; hematocrit, $29.6 \%$; reticulocyte count, $12.2 \%$; and mean corpuscular volume $90 \mathrm{fl}$. The peripheral blood had 1,580 nucleated erythrocytes/100 lymphocytes, and erythrocytes were microcytic and hypochromic with extreme anisocytosis, poikilocytosis, and targeting. Platelet count was $85,000 / \mu \mathrm{l}$; serum bilirubin, $6.4 \mathrm{mg} / \mathrm{dl}$; serum $\mathrm{IgM}, 16 \mathrm{mg} / \mathrm{dl}$; serum glutamic oxalacetic transaminase, $286 \mathrm{mg} / \mathrm{dl}$; serum glutamic pyruvic transaminase, $26 \mathrm{mg} / \mathrm{dl}$; and hepatitus Bs antigen was negative. Electrophoresis showed $\mathrm{Hb} F$ and $\mathrm{A}$, but no $\mathrm{Hb}$ Bart's. Serological tests and cultures for bacterial, protozoan, and viral infections were negative. Antiplatelet antibodies (isotype and autoimmune) were not detected. The infant received a single transfusion of $10 \mathrm{ml} / \mathrm{kg}$ with typespecific, washed, packed erythrocytes. After transfusion, the hospital course was uneventful and the patient was discharged on the 8 th hospital day with persistent microcytic anemia. Subsequent studies demonstrated normal iron stores, absence of unstable hemoglobin, and resolution of thrombocytopenia. The infant, now $2 \frac{1}{2} \mathrm{yr}$ old, has persistent mild hypochromic and microcytic anemia, but continues to grow normally.

The proposita's sister had a similar history and required prolonged hospitalization during the neonatal period. Her father, paternal aunt, uncle, grandmother, and great-grandmother have histories of anemia.

Hematologic data were obtained with the Coulter counter, model S (Coulter Electronics, Hialeah, FL). Globin chain synthesis studies were performed as previously described (13). DNA was prepared from the peripheral blood lymphocytes and digested with the enzymes EcoRI, BamHI, BglII, PstI, HpaI, HincII, AvaI, and HindIII (New England Biolabs, Beverly MA; Bethesda Research Laboratories, Gaithersburg, MD). The $\epsilon$-globin gene fragment used as hybridization probe was the EcoRI-BamHI-digested plasmid pe 1.3; the $\gamma$-probe was JW151; and $\psi \beta$ probe was the $X b a I-$ $B g l$ II fragment of plasmid $\psi \beta 1-5$ containing the entire $\psi \beta$-globin gene; and the $\beta$-probes were plasmids JW102 and the $B a m H I-E c o R I-d i g e s t e d ~ H \beta$-IS containing the intervening sequence of the $\beta$-globin gene. In addition, we used three cloned, unique sequence DNA probes: one derived from $\gamma \beta$-I plasmid was located more than $100 \mathrm{~kb} 5^{\prime}$ to the $\beta$-globin cluster; the second, from $3^{\prime} \mathrm{HPFH}$ plasmid, was located at least $60 \mathrm{~kb} 3^{\prime}$ to the gene cluster; and the third, pRK28, was $17 \mathrm{~kb} 3^{\prime}$ from the $\beta$-globin gene. The first two were isolated from the region near the break points of DNA from the patients with $\gamma \delta \beta$-thalassemia (10) and HPFH (8), respectively. The third was isolated from a Charon 4A library (14). For comparison, DNA was also digested with SstI and hybridized with a human insulin gene probe (from plasmid $\mathrm{pHuI}$ ). The $\alpha$-globin genotypes were determined by hybridization with $\alpha$-and $\zeta$-globin probes derived from plasmids JW101 and pPR $\zeta$.

In situ hybridization was also used to detect the $\beta$-globin gene complex on chromosome preparations. The probes, which were derived from plasmids pe1.3, JW151, $\psi \beta 1-5$,
$\mathrm{H} \beta$-IS, and RIH, were nick-translated to $10^{8} \mathrm{cpm} / \mu \mathrm{g}$ with $\left[{ }^{3} \mathrm{H}\right] \mathrm{dCTP}$ and $\left[{ }^{3} \mathrm{H}\right] \mathrm{TTP}$ (New England Nuclear, Boston, MA). Hybridization was performed according to the conditions described by Harper and Saunders (15). The slides were coated with Kodak $\mathrm{NTB}_{2}$ emulsion (Eastman Kodak Co., Rochester, NY) and exposed for $12 \mathrm{~d}$. Chromosomes were subsequently identified by Q-banding (16) and examined for the presence or absence of grains on the short (p) and long (q) arms. 30 consecutive cells were analyzed from each subject and each arm labeled either positive or negative. No attempt was made to correct for the number of grains on each arm or the length of the arms of the individual chromosomes.

\section{RESULTS}

The pedigree of the family and their hematologic data are presented in Fig. 1 and Table I. Members with a history of anemia have microcytic hypochromic erythrocytes, normal $\mathrm{Hb} \mathrm{A}_{2}$ and $F$ levels, and increased $\alpha /$ non- $\alpha$ globin chain synthetic ratios. This clinical picture and the occurrence of hemolytic anemia at birth strongly suggest a diagnosis of $\gamma \delta \beta$-thalassemia.

Our analysis of DNA from this family produced different results from those in the two previously reported cases of $\gamma \delta \beta$-thalassemia, in which abnormal $\beta$-globin gene-containing fragments were detected

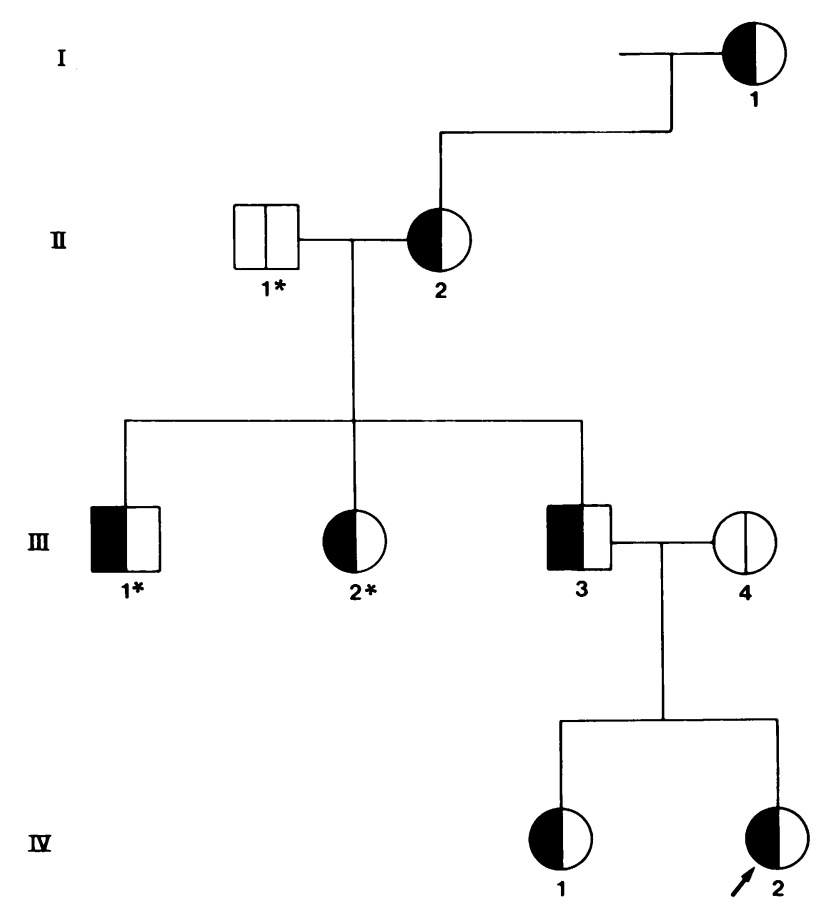

Figure 1 Pedigree of the family. The black symbols indicate family members who have a history of anemia. II-1, III-1, and III-2 (denoted by asterisks) were not available for study. The arrow indicates the proposita. 
TABLE I

Hematologic Data of the Family

\begin{tabular}{lccccccccccc}
\hline Subject & Age & Hb & Hct & RBC & MCV & MCH & MCHC; & Retic & Hb A & Hb F & $\alpha /$ non- $\alpha$ ratio \\
\hline & & $g / d l$ & $\%$ & $\times 10^{\circ} / \mu l$ & $f$ & $p g$ & $g / d l$ & $\%$ & $\%$ & $\%$ \\
I-1 & 76 & 12.8 & 39.6 & 6.08 & 65 & 21.1 & 32.4 & 2.0 & 2.9 & 0.5 & 1.8 \\
II-2 & 50 & 11.6 & 35.8 & 6.00 & 60 & 19.3 & 32.4 & 1.0 & 2.9 & 0.9 & 2.3 \\
III-3 & 30 & 13.2 & 41.1 & 6.92 & 59 & 19.1 & 32.1 & 2.2 & 3.0 & 1.3 \\
III-4 & 29 & 13.0 & 38.6 & 4.08 & 90 & 30.5 & 33.8 & 1.0 & 2.9 & 0.6 \\
IV-1 & 4 & 10.6 & 32.5 & 5.53 & 58 & 19.2 & 32.7 & 2.5 & 3.2 & 0.6 & 1.0 \\
IV-2 & 2 & 9.0 & 29.0 & 4.65 & 62 & 19.4 & 31.3 & 5.0 & 2.9 & 2.2 \\
\hline
\end{tabular}

- Globin chain synthesis study performed at 2 mo of age.

$(10,11)$. In this family, the DNA from the affected subjects produced normal-sized restriction fragments that contained the $\beta$-globin gene when digested with EcoRI, HpaI, PstI, and BamHI, and hybridized with the $\beta$-globin probe. The $\alpha$-globin genotypes were normal and additional hybridizations with $\gamma$ - and $\epsilon$-globin gene probes were also normal. However, the intensity of hybridization with the $\beta$ - and $\beta$-like globin gene probes was lighter than normal and this raised the possibility of an extensive deletion involving the entire $\beta$-globin gene cluster. Such a deletion would produce normal globin gene restriction patterns because the DNA fragments detected would be derived from the unaffected chromosome.

Several restriction sites in the $\beta$-globin gene cluster are polymorphic; a given individual is usually heterozygous for some of these sites because the paternal and maternal chromosomes are different in them (17). We studied seven of these polymorphic sites: the HincII site $5^{\prime}$ to the 6 -globin gene (17), the HindIII sites in the second intervening sequence (IVS) of the ${ }^{\mathrm{G}} \boldsymbol{\gamma}$ - and ${ }^{A} \gamma$-globin genes (18), the two HincII sites in and 3 ' to the $\psi \beta$-globin gene (17), the AvaII site in the second IVS of the $\beta$-globin gene (17), and the BamHI site $3^{\prime}$ to the $\beta$-globin gene (Table II; 19). Whereas the nor-

TABLE II

Haplotypes of the Family

\begin{tabular}{|c|c|c|c|c|c|c|c|}
\hline & \multirow{2}{*}{$\begin{array}{c}\text { Hincll } \\
5^{\prime} \epsilon\end{array}$} & \multicolumn{2}{|c|}{ HindIII } & \multicolumn{2}{|c|}{ HinclI } & \multirow{2}{*}{$\underset{\beta}{\text { Avall }}$} & \multirow{2}{*}{$\underset{3^{\prime} \beta}{B a m \mathrm{HI}}$} \\
\hline & & ${ }^{\mathrm{c}} \gamma$ & ${ }^{A} \gamma$ & $\psi \beta$ & $3^{\prime} \psi \beta$ & & \\
\hline I-1 & & -1 & -1 & -1 & -1 & $+/$ & -1 \\
\hline II-2 & +1 & +1 & -1 & +1 & +1 & +1 & +1 \\
\hline III-3 & -1 & +1 & -1 & +1 & +1 & +1 & -1 \\
\hline III-4 & $-1+$ & $+1-$ & $+1-$ & $-1-$ & $+1-$ & $-1+$ & $+1+$ \\
\hline IV-I & -1 & +1 & +1 & -1 & +1 & -1 & +1 \\
\hline IV-2 & +1 & -1 & -1 & -1 & -1 & +1 & +1 \\
\hline
\end{tabular}

mocytic family member was heterozygous for several of these sites, all members with microcytosis exhibited a single restriction pattern at each of the sites. This suggested that the $\beta$-globin gene cluster was present on one homologous chromosome only and that the affected members were hemizygous for these sites.

Detailed analysis of several sites supported this contention. Results from the Bam HI analysis are shown in Fig. 2. The DNA digest from the proposita's father (III-3) showed only a $22-\mathrm{kb}$ fragment which contained the $3^{\prime}$ portion of the $\beta$-globin gene due to the absence

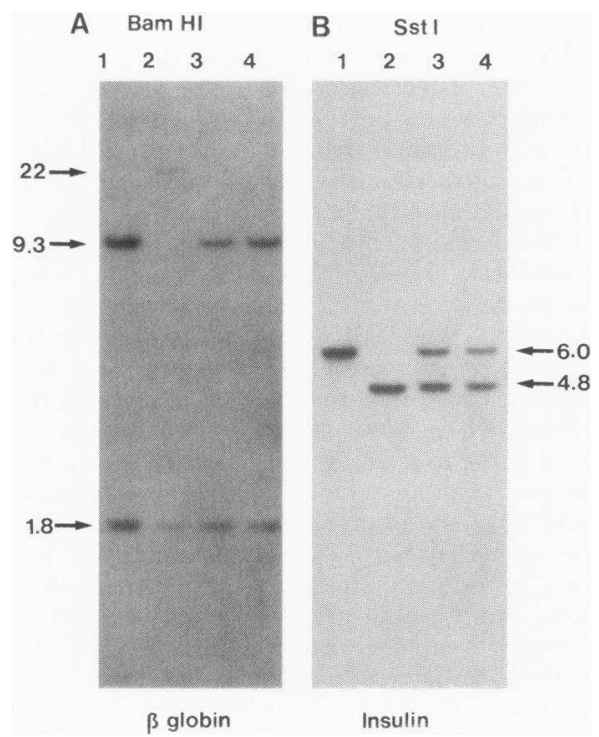

Figure 2 Autoradiographs of DNA digested with BamHI and $S s t I$ and hybridized with the $\beta$-globin and insulin gene probes, respectively. The $1.8-\mathrm{kb}$ fragment contains the $5^{\prime}$ portion of the $\beta$-globin gene, while the polymorphic Bam HI site $3^{\prime}$ to the $\beta$-globin gene results in a 9.3 - or $22-\mathrm{kb}$ fragment containing the $3^{\prime}$ portion of the gene. (1) III-4, (2) III-3, (3) IV-1, (4) IV-2. 
of the BamHI site $3^{\prime}$ to the gene. The mother's (III-4) DNA produced a 9.3-kb fragment with this enzyme because the BamHI site is present. If both parents are homozygous for these patterns, DNA from the proposita (IV-2) and her sister (IV-1) should show both the 9.3- and $22-\mathrm{kb}$ fragments. In fact, only the 9.3-kb fragment from the mother was observed, indicating that neither child inherited a $\beta$-globin gene from the father. Analysis of the HincII site at the $\psi \beta$-globin gene points to a similar conclusion. In fact, haplotype analysis of all seven restriction sites showed that the patterns carried by the two children were inherited from the two different maternal chromosomes (Table II).

As a control, we studied the inheritance of the human insulin gene. The insulin gene is also located on the short arm of chromosome 11 (20). Restriction analysis has shown a high degree of polymorphism due to variations in the length of DNA sequences $5^{\prime}$ to it (21). This polymorphism is detectable by digestion with SstI. When we digested the DNA with this enzyme, the proposita's father had a 4.8-kb SstI fragment, the mother had a $6.0-\mathrm{kb}$ fragment, and the proposita and her sister inherited the 4.8- and 6.0-kb fragments from the father and mother, respectively. These results dem- onstrate that both offspring inherited one insulin gene from each parent, but only one $\beta$-globin gene cluster from the mother.

We confirmed the decrease in $\beta$-globin gene dosage by quantitating the intensity of hybridization of the globin gene bands. A filter containing BglII-digested DNA was blotted with mixed $\alpha$ - and $\beta$-globin probes. In all family members, the $\beta$-globin gene resided in a $5.2-\mathrm{kb}$ fragment and the two $\alpha$-globin loci, $\alpha \mathrm{l}$ and $\alpha 2$, were on $7.5-\mathrm{kb}$ and $12-\mathrm{kb}$ fragments, respectively. Densitometric scans of the autoradiographs supported our conclusion that only one $\beta$-globin locus is present per diploid genome in the microcytic family members. The intensity of the $\beta$-globin band relative to the two $\alpha$-globin bands in these individuals was similar to that found in a heterozygote with the deletion type of $\delta^{0} \beta^{0}$ thalassemia $(6,7)$ and was half that of a normal subject (Fig. 3).

We estimated the extent of the deletion by hybridization with probes situated $5^{\prime}$ and $3^{\prime}$ to the $\beta$-globin gene cluster. Hybridization of TaqI-digested DNA with the $\gamma \beta$-I probe located over $100 \mathrm{~kb} 5^{\prime}$ to the $\beta$ globin gene cluster yielded a $3.6-\mathrm{kb}$ fragment from the proposita's mother and a 2.3-kb fragment from her father (Fig. 4). The proposita inherited only the 3.6-

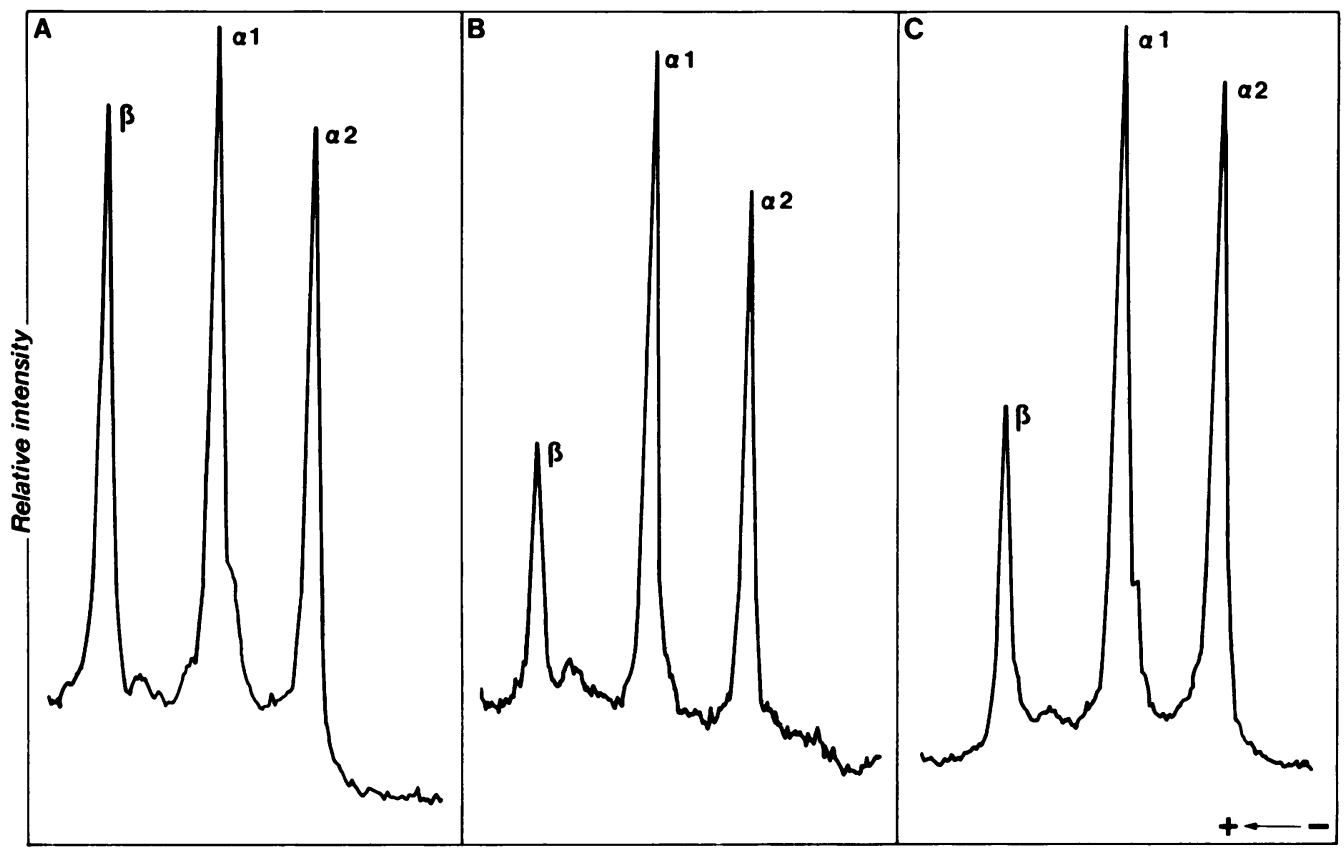

FIGURE 3 Densitometric scanning of autoradiographs from DNA digested with BglII and hybridized with mixed $\alpha$ - and $\beta$-globin probes. The arrow shows the direction of electrophoresis. The sizes of the DNA fragments are: $\beta, 5.2 \mathrm{~kb} ; \alpha 1,7.5 \mathrm{~kb}$; and $\alpha 2,12 \mathrm{~kb}$. (A) normal (III-4), (B) proposita (IV-2), 2, and (C) a heterozygote for the deletion type of $\delta^{0} \beta^{0}$ thalassemia. 


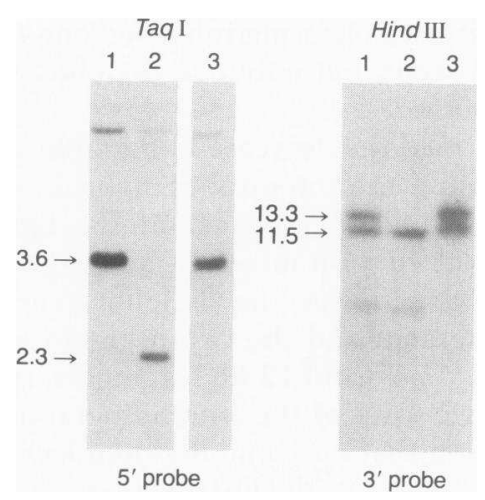

Figure 4 Autoradiographs of DNA digested with TaqI and HindIII. The Taql-digest was hybridized with a $\gamma \beta$-I probe located at least $100 \mathrm{~kb} 5^{\prime}$ to the $\beta$-globin cluster; the HindIII digest was hybridized with a pRK 28 probe located $17 \mathrm{~kb} \mathrm{3}$ to the $\beta$-globin gene. (1) III-4, (2) III-3, (3) IV-2.

$\mathrm{kb}$ fragment from her mother, demonstrating that the deletion extends from at least $100 \mathrm{~kb} 5^{\prime}$ to the $\beta$-globin gene cluster on the affected chromosome. Then, with a probe located at least $60 \mathrm{~kb} 3^{\prime}$ to the $\beta$-globin gene cluster, we hybridized to DNA digested with $B a m \mathrm{HI}$, EcoRI, BglII, or HindIII, and detected no differences in restriction patterns or intensity of hybridization between the normal and affected members. This indicates that this region of the DNA is not deleted (data not shown). We also used a probe (pRK28) located 17 $\mathrm{kb}$ from the $\beta$-globin gene to determine the end point of the $3^{\prime}$ deletion. A polymorphic HindIII site $7 \mathrm{~kb} 3^{\prime}$ to the $\beta$-globin gene results in 11.5- or 13.3-kb HindIII fragments with the pRK28 probe $(22)$. The father has an 11.5-kb fragment and the mother has both the 11.5and 13.3-kb fragments. The proposita has both fragments and must have inherited the $11.5-\mathrm{kb}$ fragment from her father and the 13.3-kb fragment from her mother (Fig. 4). These results indicate that the HindIII site $7 \mathrm{~kb}$ from the $\beta$-globin gene is intact and that the $3^{\prime}$ breakpoint of the deletion lies between this site and the $3^{\prime}$ end of the $\beta$-globin gene.

We also documented the absence of the $\beta$-globin gene cluster on one chromosome 11 homolog in the affected individuals by in situ hybridization (Fig. 5). The short arm of chromosome 11 (11p) from the proposita's mother (III-4) showed the most frequent hybridization to the $\beta$-like probes when compared with the other chromosome arms. In contrast, the $11 \mathrm{p}$ from the proposita (IV-2) and her father (III-4) hybridized half as frequently (Fig. 6). We analyzed 30 cells from

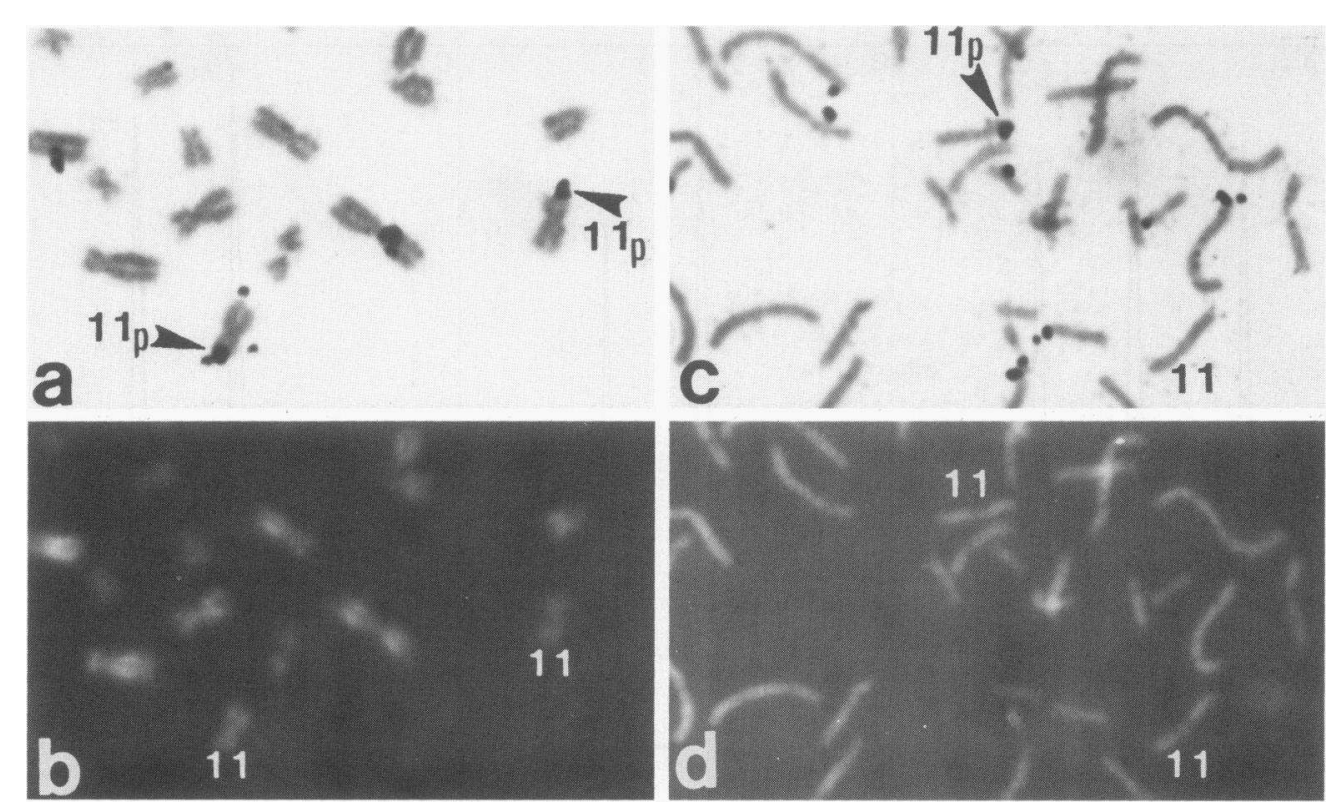

FIGURE 5 Representative metaphase spread showing labeled chromosomes after hybridization with ${ }^{3} \mathrm{H}$-globin gene cluster probes. (a) Partial metaphase spread from the normal individual (III-4). The short arms of both chromosomes 11 were labeled (indicated by arrows). (b) Qbanding chromosome preparation from the same spread as $a$ obtained by sequential staining with quinacrine dihydrochloride. The two chromosomes 11 are indicated. (c) Partial metaphase from proposita (IV-2) with the short arm of a chromosome 11 labeled. (d) Q-banding chromosome preparation from the same spread as $c$. 


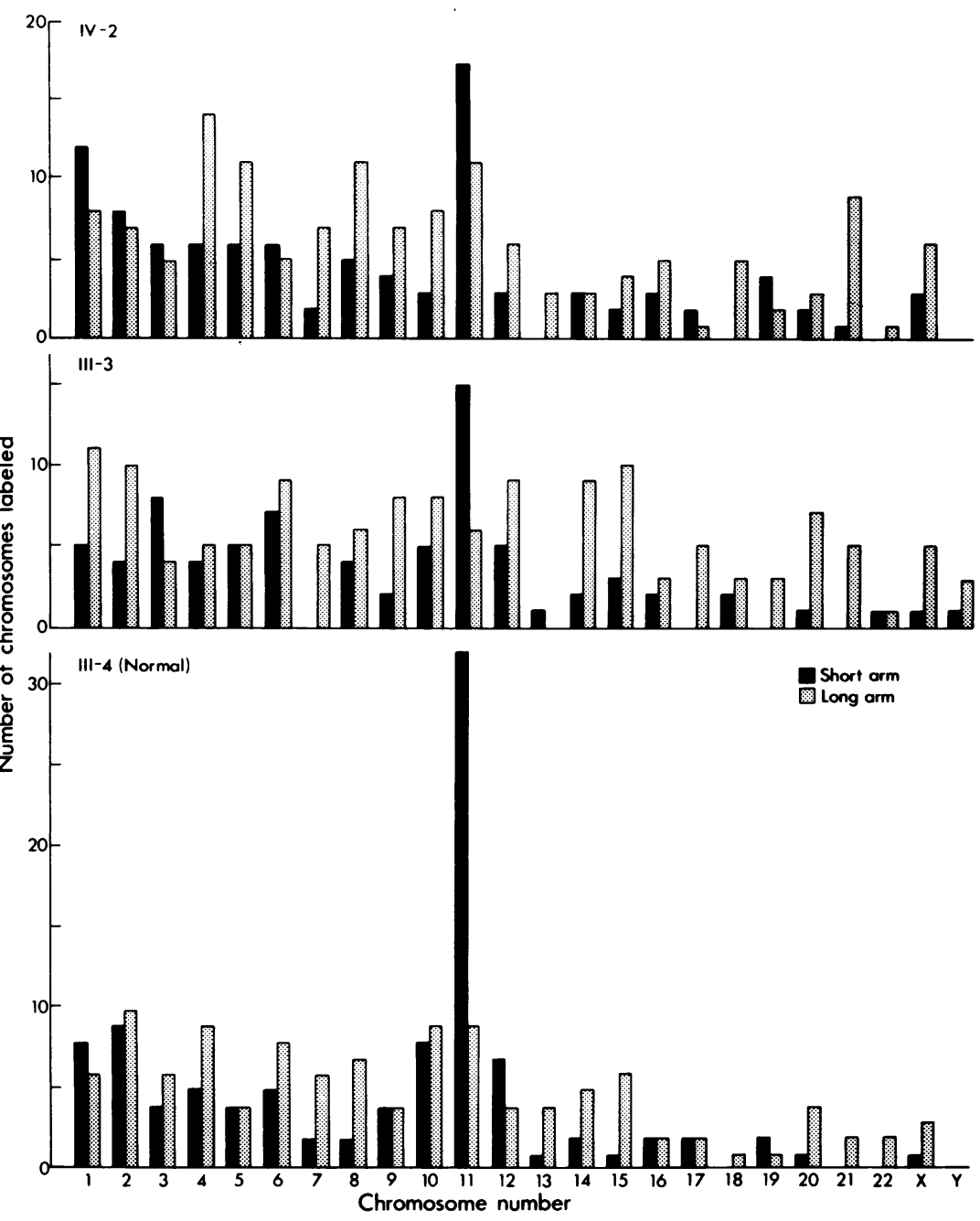

Figure 6 Frequency distribution of labeled specific chromosome arms from 30 consecutive metaphase spreads examined from the proposita (IV-2), her father (III-3), and her mother (III-4).

each of these three individuals and counted the number of cells in which both $11 \mathrm{p}$ homologs were labeled. In III-4, 8 cells $(26.7 \%$ ) showed hybridization in both homologs, whereas no such cells were found in III-3 or IV-2 (Table III). We were able to obtain such a high frequency of hybridization by using five probes along the $\beta$-globin cluster.

\section{DISCUSSION}

We have described four generations of a family in which a new type of gene deletion involves a $100-\mathrm{kb}$ region encompassing the entire $\beta$-globin cluster, and produces a $\gamma \delta \beta$-thalassemia syndrome. Heterozygosity for this deletion produces hypochromia, microcytosis, normoblastemia, and hemolytic anemia at birth. Affected adults exhibit microcytic hypochromic erythrocytes, normal $\mathrm{Hb} \mathrm{A}_{2}$ and $\mathrm{F}$ levels, and a decreased

TABLE III

In Situ Hybridization of the $\beta$-Globin Gene Probes in 30 Consecutive Cells

\begin{tabular}{lllrl}
\hline & \multicolumn{3}{c}{$\begin{array}{c}\text { No. (and percentage) of cells showing } \\
\text { positive hybridization }\end{array}$} & No. of positive \\
& Both 11p & One 11p & Neither 11p & \begin{tabular}{c} 
chromosomes \\
\cline { 2 - 4 }
\end{tabular} \\
\hline III-4 & $8(26.7)$ & $18(60.0)$ & $4(13.3)$ & 34 \\
III-3 & 0 & $15(50.0)$ & $15(50.0)$ & 15 \\
IV-2 & 0 & $17(53.3)$ & $13(46.7)$ & 17 \\
\hline
\end{tabular}


$\beta / \alpha$-globin chain synthetic ratio. Homozygosity for this gene is probably lethal since the fetus would not produce any embryonic or fetal hemoglobins.

Because fragments containing the $\beta$-like globin genes were all derived from the unaffected chromosome, initial Southern analysis did not reveal any rearrangement in the DNA. The $\beta$-like globin genes from the affected chromosome were all deleted and therefore not represented on the blot analysis. We confirmed the existence of only one $\beta$-globin gene cluster per diploid genome in four different ways. Firstly, none of the microcytic individuals were heterozygous for any of the restriction endonuclease sites commonly known to be polymorphic in human populations. Secondly, a comparison of the polymorphic restriction patterns of two sets of genes on the short arm of chromosome 11 revealed that the two children inherited only the maternal genes for the $\beta$-globin and $\beta$-like globin genes, but both paternal and maternal patterns for the insulin gene. Thirdly, the intensity of hybridization of the $\beta$-globin probe with the DNA from affected individuals was half the normal level. Hybridization with DNA probes upstream and downstream from the $\beta$-globin gene cluster demonstrated that the deletion starts over $100 \mathrm{~kb} 5^{\prime}$ to the $\beta$-globin gene cluster and extends to within $7 \mathrm{~kb} 3^{\prime}$ to it.

Finally, we studied the abnormal chromosomes in this family by in situ hybridization. Five different unique sequence probes were used to increase the intensity of hybridization. With this method, positive signals were obtained in $12 \mathrm{~d}$ instead of the 6-wk exposure time reported in other in situ studies of globin genes (23). Under these hybridization conditions, $\sim 50 \%$ of the $11 \mathrm{p}$ are labeled in a normal individual. The expected percentage of cells in which both homologs in the cell are labeled is 25 , which approximates the percentage found in the normal family member. In contrast, the two thalassemic individuals had no cells in which both $11 \mathrm{p}$ were labeled. These data directly demonstrate that the $\beta$-globin cluster is deleted from one $11 p$ homolog.

Many different molecular lesions cause thalassemia (4). A single phenotype can arise through several different mutational events. Thus, in addition to the two lesions that have already been described for $\gamma \delta \beta$-thalassemia, this study defines a new gene deletion that produces the same syndrome. Recently, Kazazian et al. (24) described a similar extensive deletion producing this syndrome in a family of Mexican origin. It is not known whether these two extensive deletions are similar.

The frequency of the deletion described has not been determined. In view of the increasing number of cases reported, differential diagnosis of hemolytic disease of the newborn should include $\gamma \delta \beta$-thalassemia when the erythrocytes show microcytosis. As this study illustrates, a normal DNA restriction pattern does not necessarily exclude this diagnosis.

\section{ACKNOWLEDGMENTS}

We thank Dr. Tom Maniatis for the pBR $\zeta, p \in 1.3, \mathrm{H} \beta$-IS, and RIH probes; Dr. Bernard Forget and Dr. Edward J. Benz, Jr. for the JW101, JW102, JW151, and $\psi \beta 1-5$ probes; Dr. Elio Vanin for the $\gamma \beta$-I plasmid and 3' HPFH probes; Dr. Russell Kaufman for the pRK28 probe; Dr. Howard Goodman and Dr. Barbara Cordell for the insulin gene probe; and Jennifer Gampell for editorial comments.

This work was supported in part by grant AM 16666 from the National Institutes of Health and a grant from UNICO National, Inc.

\section{REFERENCES}

1. Deisseroth, A., A. Nienhuis, J. Lawrence, R. Giles, P Turner, and F. H. Ruddle. 1978. Chromosomal localization of human $\beta$ globin gene in human chromosome 11 in somatic cell hybrids. Proc. Natl. Acad. Sci. USA. 75:1456-1460.

2. Lebo, R. V., A. V. Carrano, K. Burkhart-Schultz, A. M. Dozy, L.-C. Yu, and Y. W. Kan. 1979. Assignment of human $\beta-, \gamma$ - and $\delta$-globin genes to the short arm of chromosome 11 by chromosome sorting and DNA enzyme analysis. Proc. Natl. Acad. Sci. USA. 76:58045808.

3. Fritsch, E. F., R. M. Lawn, and T. Maniatis. 1980. Molecular cloning and characterization of the human $\beta$-like globin gene cluster. Cell. 19:959-972.

4. Weatherall, D. J., and J. B. Clegg. 1982. Thalassemia revisited. Cell. 29:7-9.

5. Orkin, S. H., R. Kolodner, A. Michaelson, and R. Husson. 1980. Cloning and direct examination of a structurally abnormal human $\beta^{0}$-thalassemia globin gene. Proc. Natl. Acad. Sci. USA. 77:3558-3562.

6. Fritsch, E. F., R. M. Lawn, and T. Maniatis. 1979. Characterization of deletions which affect the expression of fetal globin genes in man. Nature (Lond.). 279:598-603.

7. Ottolenghi, S., B. Giglioni, P. Comi, A. M. Gianni, E. Polli, C. T. A. Acquaye, J. H. Oldham, and G. Masera. 1979. Globin gene deletion in HPFH, $\delta^{0} \beta^{0}$ thalassemia and $\mathrm{Hb}$ Lepore disease. Nature (Lond.). 278:654-657.

8. Tuan, D., M. J. Murname, J. F. deRiel, and B. G. Forget. 1980. Heterogeneity in the molecular basis of hereditary persistence of fetal hemoglobin. Nature (Lond.). 285:335337.

9. Bernards, R., and R. A. Flavell. 1980. Physical mapping of the globin gene deletion in hereditary persistence of fetal hemoglobin (HPFH). Nucleic Acids Res. 8:15211534.

10. van der Ploeg, L. H. T., A. Konings, M. Oort, D. Roos, L. Bernini, and R. A. Flavell. 1980. $\gamma-\beta$ thalassemia studies showing that deletion of the $\gamma$ - and $\delta$-genes influences $\beta$-globin gene expression in man. Nature (Lond.). 283:637-642.

11. Orkin, S. H., S. C. Goff, and D. G. Nathan. 1981. Heterogeneity of DNA deletion in $\gamma \delta \beta$-thalassemia. J. Clin. Invest. 67:878-884.

12. Kan, Y. W., B. G. Forget, and D. G. Nathan. 1972. Gamma-beta thalassemia: a cause of hemolytic disease of the newborn. N. Engl. J. Med. 286:129-134.

13. Kan, Y. W., E. Schwartz, and D. G. Nathan. 1968. Globin 
chain synthesis in the alpha thalassemia syndromes. $J$. Clin. Invest. 47:2515-2522.

14. Kaufman, R. E., P. J. Kretschmer, J. W. Adam, H. C. Coon, W. F. Anderson, and A. W. Nienhuis. 1980. Cloning and characterization of DNA sequences surrounding the human $\gamma-, \delta$-, and $\beta$-globin genes. Proc. Natl. Acad. Sci. USA. 77:4229-4237.

15. Harper, M. E., and G. F. Saunders. 1981. Localization of single copy DNA sequences on Q-banded human chromosomes by in situ hybridization. Chromosoma (Berl.). 83:431-439.

16. Lin, C. C., J. H. van de Sande, W. K. Smink, and D. R. Newton. 1975. Quinacrine fluorescence and Q-banding patterns of human chromosomes. I. Effects of varying factors. Can. J. Genet. Cytol. 17:81-92.

17. Antonarakis, S. E., C. D. Boehm, P. J. V. Giardina, and H. H. Kazazian, Jr. 1982. Non-random association of polymorphic restriction sites in the $\beta$-globin gene cluster. Proc. Natl. Acad. Sci. USA. 79:137-141.

18. Jeffreys, A. J. 1979. DNA sequence variants in the ${ }^{G} \gamma-,{ }^{A} \gamma-, \delta$-, and $\beta$-globin genes of man. Cell. 18:1-10.

19. Kan, Y. W., K. Y. Lee, M. Furbetta, A. Angius, and A. Cao. 1980. Polymorphism of DNA sequence in the $\beta$ globin gene region. N. Engl. J. Med. 302:185-189.
20. Owerbach, D., G. I. Bell, W. J. Rutter, and T. B. Shows. 1980. The insulin gene is located on the short arm of chromosome 11 in humans. Diabetes. 30:267-270.

21. Bell, G. I., J. H. Karam, and W. J. Rutter. 1981. Polymorphic DNA region adjacent to the $5^{\prime}$ end of the human insulin gene. Proc. Natl. Acad. Sci. USA. 78:5759-5763.

22. Forget, B. G., D. Tuan, M. V. Newman, E. A. Finegold, F. Collins, Y. Fukumaki, P. Jagadeeswaran, and S. M. Weissman. 1983. Molecular studies of mutations that increase $\mathrm{Hb} \mathrm{F}$ productivity in man. In Hemoglobin Switching. G. Stamatoyannopoulos, A. Nienhuis, editors. Alan R. Liss, New York. In press.

23. Malcolm, S., P. Barton, C. Murphy, and M. A. FergusonSmith. 1981. Chromosomal localization of a single copy gene by in situ hybridization-human $\beta$-globin genes on the short arm of chromosome 11. Ann. Hum. Genet. 45:135-141.

24. Kazazian, H. H., Jr., E. R. Fearon, P. G. Waber, J. I. Lee, S. E. Antonarakis, S. H. Orkin, E. F. Vanin, P. S. Heathorn, F. G. Grosveld, and G. R. Buchanan. 1982. $\gamma \delta \beta$ thalassemia. Deletion of the entire $\beta$-globin gene cluster. Blood. 60(Suppl.):54a. 